\section{Penting nya Persatuan} dan Kesatuan Untuk

\section{Mencegah Radikalisme}

\section{Danang Fahturosi}

IIK STRADA INDONSIA

ryancoper2033@gmail.com

\section{Abstrak}

Radikalisme merupakan paham atau aliran yang terkait dengan perubahan besar dan ekstrem. Radikalisme adalah gerakan yang sudah ada sejak abad ke-18 di Eropa. Kini radikalisme adalah konsep yang banyak ditentang dan diperangi karena banyak terkait dengan kekrasan.

Kejahatan Radikalismeterorisme sudah banyak terjadi di lintas negara, melibatkan jaringan yang sangat besar, sehingga sangat sulit dicegah. Indonesia adalah salah satu negara yang rentan terjadi radikalisme karena banyak nya keberagaman suku budaya dan agama gerakan terorisme dan radikalisme memberikan dampak bagi keberlangsungan sosial, ekonomi dan budaya dalam masyarakat. Kejahatan teroris dapat menimbulkan permasalahan seperti kekacauan sosial, ekonomi dan politik dalam masyarakat.

Kata kunci:persatuan dan

kesatuan,radikalisme,terorisme

\section{Latar Belakang}

Radikalisme merupakan paham atau aliran yang terkait dengan perubahan besar dan ekstrem. Radikalisme adalah gerakan yang sudah ada sejak abad ke-18 di Eropa. Kini radikalisme adalah konsep yang banyak ditentang dan diperangi karena banyak terkait dengan kekrasan.

Kejahatan Radikalismeterorisme sudah banyak terjadi di lintas negara, melibatkan jaringan yang sangat besar, sehingga sangat sulit dicegah. Indonesia adalah salah satu negara yang rentan terjadi radikalisme karena banyak nya keberagaman suku budaya dan agama gerakan terorisme dan radikalisme memberikan dampak bagi keberlangsungan sosial, ekonomi dan budaya dalam masyarakat. Kejahatan teroris dapat menimbulkan permasalahan seperti kekacauan sosial, ekonomi dan politik dalam masyarakat.

Dengan memperhatikan dampak terorisme dan gerakan radikalisme yang sangat membahayakan negara 
dan masyarakat, maka selalu waspada terkait dengan suatu sikap dalam hubungannya dengan nasionalisme yang dibangun dari rasa peduli dan rasa tanggung jawab seseorang warga Negara terhadap kelangsungan kehidupan nasionalnya, kehidupan bermasyarakat, berbangsa dan bernegara dari suatu ancaman. Jadi dituntut adanya suatu kepedulian terhadap kerawanan yang dapat mengancam negara bangsa harus bisa mendeteksi dan mencegah jika ada kegiatan-kegiatan yang mengarah ke radikal, jika ada indikasi atau gejala semacam itu,kita harus cepat melaporkan ke aparat berwenang. Untuk itu semua perlu waspada apalagi sebagai warganegara Indonesia sangat diperlukan kewaspadaan nasional

\section{Kasus/masalah}

Radikalisme di Indonesia sudah terekam sejak lama. Kelompok atau organisasi yang mempratikkan paham-paham radikal pun jumlahnya tidak sedikit dan terus bertambah.

\section{Tinjauan putaka}

Dalam Kamus Besar Bahasa Indonesia (Depdiknas,2002), radikalisme diartikan sebagai paham atau aliran yang menginginkan perubahan atau pembaharuan sosial dan politik dengan cara kekerasan atau drastis. Radikalisme juga memiliki penilaian berbeda terhadap situasi politik yaitu membenarkan bahkan membutuhkan tindak kekerasan menyangkut politik (political violence) sebagai satusatunya jalan untuk mengubah kondisi politik (Moskalenko dan McCauley ,2009). Radikalisme menurut Cross (2013) yaitu sebagai: 1) Istilah dalam lingkup gerakan sosial maupun politik yang berarti sebuah proses, praktik, atau serangkaian keyakinan dari keadaan non-radikal menjadi radikal. Praktik radikalisme sering diasosiasikan dengan sejumlah taktik dan strategi yang berada di luar lingkup aksi protes politis maupun religius yang dapat diterima, bahkan menjurus ilegal. 2) Radikalisme merepresentasikan sisi ekstrim dari (kurva) distribusi aksi politik yang dapat diterima dan radikalisme dapat melibatkan aksi kekerasan atas dasar keyakinan, bukan personal. 3) Radikalisme dapat merujuk pada keyakinan tentang cara terbaik untuk meraih tujuan gerakan. Keyakinan radikal mengembangkan perasaan bahwa cara yang diterima (oleh masyarakat) untuk mengubah keadaan tidaklah cukup dan langkah-langkah luar biasa harus ditempuh. Dengan demikian dapat disimpulkan bahwa radikalisme adalah suatu pahamyang dibuat oleh sekelompok aliran yang 
menginginkan perubahan atau pembaharuan sosial atau politik secara drastic dengan menggunakan cara-cara kekerasan untuk mencapai perubahan kondisi politik.

\section{Pembahasan}

Radikalisme di Indonesia memang sudah terekam sejak lama. Kelompok atau organisasi yang mempratikkan paham-paham radikal pun jumlahnya tidak sedikit dan terus bertambah. Sebut saja organisasi Daarul Islam (DI/TII) yang gencar menggeser konstitusi dan ideologi Pancasila untuk membangun negara Islam pada masa awal kemerdekaan Indonesia. As'ad Said Ali (2012) dalam Ideologi Gerakan PascaReformasi menyatakan bahwa berbagai organisasi/gerakan Islam non-mainstream berpaham radikal terus menjamur pasca runtuhnya rezim Orde Baru seperti kelompok Ikhwanul Muslimim, Hizbut Tahrir Indonesia, Jamaah Islamiyah, Jamaah Ansharut Daulah, dan masih banyak lagi. Tentu saja radikalisme tidak muncul begitu saja dari ruang hampa. Ahmad Najib Burhani mengatakan bahwa dari segi teologis radikalisme terjadi akibat dari penafsiran teks-teks agama secara literal tanpa melihat konteks historis dan sosiologis sehingga teks-teks tersebut sering kali diklaim untuk melegitimasi tindakan kekerasan. Gelombang radikalisme di berbagai negara Muslim juga bisa terjadi karena rasa solidaritas global atau ungkapan perasaan senasib yang menimpa umat Islam di berbagai negara seperti Palestina, Kashmir, Afghanistan, dan Iraq. Di sisi lain, Ayzumardi Azra mengatakan bahwa radikalisme bisa terjadi di berbagai belahan dunia manapun (termasuk di Indonesia) salah satunya sebagai respons dari otoritarianisme. Misalnya, di Era Orde Baru, wacana gerakan Islam sebagai common enemy terus dibangun untuk melanggengkan hegemoni militeristik. Fenomena ini juga muncul sebagai penolakan terhadap westernisasi dan modernisasi yang dianggap telah membuat sebagian besar negaranegara Timur kalah dalam kompetisi global sehingga radikalisme biasanya diambil sebagai jalan keluar untuk lepas dari jeratan hegemoni Barat. Selain itu, publikasi media pers Barat yang kerap melakukan framing negatif terhadap umat Islam di dunia, khususnya pascatragedi pengeboman WTC 9/11 juga berperan dalam membangkitkan radikalisme di negara-negara Timur.

dampak yang ditimbulkan oleh kelompok radikal maupun teroris terhadap Negara adalah: 
1. Dampak terhadap ideologi.

Terorisme sanga bertentangan dengan ideologi Pancasila, yang sangat bertentangan dengan kelima silanya terutama prinsip ketuhanan dan kemanusiaan,

2. Dampak terhadap agama, terorisme dengan sepihak mengklaim membela saudarasaudara seagamanya, justru mempermalukan agama itu sendiri.

3. Dampak terhadap politik, beragam aksi teroris baik besar maupun kecil di tanah air telah banyak memberikan dampak politik bagi Indonesia dalam pergaulan internasional.

4. Dampak terhadap ekonomi, sangat jelas aksi terorisme telah berdampak buruk bagi ekonomi nasional

5. Dampak terhadap kedaulatan dan pertahanan, aksi terorisme yang terjadi seakan ingin menceraikan antara pemerintah dengan warganya

Faktor yang melatar belakangi munculnya paham radikalisme

1.Faktor pemikiran Radikalisme dapat muncul dan berkembang karena yakin jika segala sesuatunya harus diubah ke arah yang kelompoknya inginkan,

2.Faktor ekonomi Radikalisme bisa dipengaruhi oleh faktor permasalahan ekonomi. Karena manusia akan berusaha sekeras mungkin untuk memenuhi kebutuhan hidupnya,

3.Faktor politik Radikalisme bisa muncul dan berkembang ketika sekelompok orang merasa pemerintah negara tidak adil kepada rakyatnya.

4.Faktor sosial Radikalisme dapat disebarkan dengan memengaruhi pemikiran orang lain. Terlebih lagi jika orang tersebut berpikiran sempit dan mudah percaya kepada pihak yang dianggap membawa perubahan ke dalam hidupnya.

5.Faktor psikologis Radikalisme dapat tumbuh dan berkembang dalam diri seseorang yang memiliki berbagai permasalahan, rasa benci, serta dendam

6.Faktor pendidikan Radikalisme dapat muncul di berbagai tempat, termasuk sarana pendidikan. Ideologi radikalisme bisa dengan mudah disisipkan dalam pengajaran.

\section{Kesimpulan}

Radikalisme yang berujung pada tindakan terorisme terbukti telah menghancurkan banyak negara. Jika hal ini tidak dicegah sejak awal, Indonesia akan tercerai-berai. Oleh karena itu, pemerintah dan masyarakat harus saling bekerjasama 
untuk melawan dan mencegah tumbuhnya paham-paham radikal. maka diperlukan kewaspadaan terkait dengan sikap nasionalisme yang terbangun dari rasa persatuan dan kesatuan dan rasa tanggung jawab seseorang warga Negara terhadap kelangsungan nasionalnya, , jika ada indikasi radikalisme,kita harus cepat melaporkan ke aparat berwenang. Jadi sangat dibutuhkanya suatu kewaspadaan terhadap ancamanancaman yang bersifat terorisme dan yang berbau radikalisme. Dalam menjaga kesatuan dan persatuan Negara Kesatuan Republik Indonesia (NKRI) maka diperlukan suatu kepedulian terhadap suatu kerawanankerawanan yang dapat mengancam.

\section{Daftar pustaka}

Hikam, M. A. (2016). Pendidikan Multikultural dalam Rangka Memperkuat Kewaspadaan Nasional Menghadapi Ancaman Radikalisme di Indonesia. Global: Jurnal Politik Internasional. 17(1). 1-17.

https://doi.org/10.7454/global.v17i1.26

Jazuli, A. (2017). Strategi Pencegahan

Radikalisme dalam Rangka Pemberantasan

Tindak Pidana Terorisme (Prevention Strategy

of Radicalism in Order To Wipe Out The

Terrorism Crime). Jurnal Ilmiah Kebijakan

Hukum. 10(2). 197- 209.

http://dx.doi.org/10.30641/kebijakan.2016.V10

$.197-209$
Mukhtar, S. (2016). Strategi Pemerintah Indonesia Menghadapi Terorisme dalam Era Demokratisasi. Reformasi. 6(2). 143-153.

Asrori, A. (2015). Radikalisme Di Indonesia: Antara Historisitas dan Antropisitas. Kalam, 9(2), 253-268. 